\title{
Expression of CD24 and B7-H3 in breast cancer and the clinical significance
}

\author{
FANG $\mathrm{CONG}^{1}$, HAITAO $\mathrm{YU}^{2}$ and XIUHUA GAO ${ }^{3}$ \\ ${ }^{1}$ Department of General Surgery, Weihai Wendeng People's Hospital; Departments of ${ }^{2}$ Clinical Laboratories \\ and ${ }^{3}$ Breast Surgery, Weihai Central Hospital, Weihai, Shandong 264400, P.R. China
}

Received July 7, 2017; Accepted September 14, 2017

DOI: $10.3892 / \mathrm{ol} .2017 .7142$

\begin{abstract}
This study aimed to investigate the correlation between the expression of CD24 and B7-H3 in breast cancer tissues and the clinical significance. Expression of CD24 and B7-H3 in breast cancer and adjacent tissues were detected by immunohistochemistry. Quantitative PCR was used to detect the expression of CD24 and B7-H3 mRNA in breast cancer and adjacent tissues. The expression of CD24 and B7-H3 protein in breast cancer and adjacent tissues was detected by immunoblotting. The correlation between the expression levels of the two proteins was analyzed and the relationship between the expression of two proteins and the 5-year survival of breast cancer patients was investigated. CD24 and B7-H3 were positively expressed in breast cancer and adjacent tissues, the CD24-positive rate was 75.7 and $25.7 \%$, respectively, and the B7-H3-positive rate was 56.8 and $43.2 \%$, respectively, and the differences were statistically significant $(\mathrm{P}<0.05)$. The expression of CD24 was positively correlated with the expression of B7-H3 (Spearman's correlation coefficient $\mathrm{r}, 0.297 ; \mathrm{p}=0.036)$. The positive and negative expression of CD24 and B7-H3 significantly affected the 5-year survival of breast cancer patients $(\mathrm{P}<0.05)$. Quantitative PCR results showed that the expression levels of CD24 and B7-H3 mRNA in breast cancer tissues were significantly higher than those in adjacent tissues $(\mathrm{P}<0.05)$. The expression levels of CD24 and B7-H3 protein in breast cancer tissues were also significantly higher than those in adjacent tissues $(\mathrm{P}<0.05)$. CD24 and B7-H3 were highly expressed in breast cancer, suggesting that both CD24 and B7-H3 were related to the development of breast cancer. Five-year survival analysis of breast cancer patients showed that the high expression of CD24 and B7-H3 were correlated with the poor prognosis of patients. Thus, CD24 and B7-H3 may become new targets for the treatment of breast cancer.
\end{abstract}

Correspondence to: Dr Xiuhua Gao, Department of Breast Surgery, Weihai Central Hospital, 3 West Mishandong Road, Weihai, Shandong 264400, P.R. China

E-mail: jgc5cs@163.com

Key words: CD24, B7-H3, breast cancer

\section{Introduction}

Breast cancer has the highest mortality rate among all the female malignant tumors (1). Primary tumors can be easily treated, while metastatic tumor is the culprit leading to the death of patients (2). Therefore, it is imperative to study the occurrence and development of tumor metastasis.

As a kind of glycosyl-phosphatidyl inositol anchored protein, CD24 is an adhesion molecule of selectin ligands (3). It has been reported that CD24 expression can promote tumor cell infiltration and metastasis (4). As a member of the B7 family, B7-H3 has a synergistic effect that can reduce immune response in the body, thereby inhibiting T-cell proliferation (4). It has been reported that abnormal expression of B7-H3 is detected in gastric cancer (5), prostate cancer (6), non-small cell lung cancer (7) and other malignant tumors. However, to the best of our knowledge, no studies on the expression of CD24 and B7-H3 in breast cancer have been reported.

In this study, the expression levels of CD24 and B7-H3 in breast cancer tissue were investigated to provide new targets for immunotherapy of breast cancer, as well as a theoretical basis for the diagnosis, treatment and prognosis of breast cancer.

\section{Materials and methods}

Experimental materials. A total of 74 breast cancer tissues and 74 adjacent tissues diagnosed by pathological examination were selected. After paraffin-embedding, tissues were cut into $4 \mu \mathrm{m}$ sections. This study was approved by the Ethics Committee of Weihai Wendeng People's Hospital (Shandong, China). Signed written informed consent was obtained from the patients and/or guardians.

Major reagents. Rabbit anti-human CD24 monoclonal antibody (Beijing Donglinchangsheng Biotechnology Co., Ltd., Beijing, China); rabbit anti-human B7-H3; goat anti-rabbit secondary antibody and endogenous control glyceraldehyde 3-phosphate dehydrogenase (GAPDH) antibody, all from BD Biosciences (Franklin Lakes, NJ, USA); diaminobenzidine (DAB) color reagent and citrate buffer powder, both from Shanghai Xinyu Biotechnology Co., Ltd., (Shanghai, China); immunohistochemistry kit (BASF-Ypc Co., Ltd., Nanjing, China); reverse transcription kit (Boyishengwu, 
Shanghai, China); real-time quantitative PCR kit (Vipotion Biotechnology Co., Ltd., Guangzhou, China); TRIGene reagent (GenStarBiosolutions Co., Ltd., Beijing, China); cell total protein extraction kit (Keygentec, Inc., Nanjing, China) and BCA protein quantitation kit (Nanjing Senbeijia Biotechnology Co., Ltd., Nanjing, China) were all used in the present study.

\section{Experimental methods}

Immunohistochemical staining. Paraffin-embedded sections were dewaxed and then washed with phosphate-buffered saline (PBS). In order to reduce the non-specific background staining caused by endogenous peroxidase, tissue sections were blocked in blocking fluid for $20 \mathrm{~min}$. After blocking with $10 \%$ serum for $10 \mathrm{~min}$, tissue sections were incubated with $\mathrm{NF}-\kappa \mathrm{B}$ primary antibody and with PTEN primary antibody (1:50) overnight at $4^{\circ} \mathrm{C}$. After washing with PBS, the tissue sections were incubated with secondary antibody (1:50) at room temperature for $30 \mathrm{~min}$. After washing with PBS again, the tissue sections were incubated with streptavidinperoxidase solution at room temperature for $30 \mathrm{~min}$. After washing with PBS, DAB color development was performed. After washing with distilled water and counter-staining, the slides were sealed.

Evaluation of immunohistochemical results. A total of 100 cells were selected in each visual field, and the average number of positive cells was calculated. The criteria for scoring were: 0-2 points: no coloring, weak coloring and strong coloring, respectively. The positive rate of stained cells was: 1-4 points: the percentage of positive cells of $1-25 \%, 26-50 \%$, $51-75 \%$ and $76-100 \%$, respectively. The product of these two scores was calculated and scores of 1 to 2 were considered to be negative and from 3 to 8 points were considered to be positive.

Quantitative PCR used to determine the expression of CD24 and B7-H3 $m R N A$. Total RNA of breast cancer and adjacent tissues was extracted according to the instructions of the TRIGene kit. The concentration and purity of RNA samples were determined by a spectrophotometer (Jingke $722 \mathrm{~N}$, Shanghai, China). Only RNA samples with a ratio of A260/ A280 between 1.8 and 2.0 were used for reverse transcription to synthesize cDNA. Primers used for PCR reaction were synthesized by Shanghai JiRan Biotechnology Co., Ltd., (Shanghai, China) (Table I).

PCR reaction conditions were performed according to the instructions of the reverse transcription-quantitative PCR kit with a reaction system of $25 \mu 1$. PCR reaction conditions were: $95^{\circ} \mathrm{C}$ for $10 \mathrm{~min}$, followed by 40 cycles of $95^{\circ} \mathrm{C}$ for $30 \mathrm{sec}$ and $59.4^{\circ} \mathrm{C}$ for $30 \mathrm{sec}$. With GAPDH endogenous control, the relative expression levels of $\mathrm{CD} 24$ and $\mathrm{B} 7-\mathrm{H} 3$ mRNA were automatically calculated by the RT-qPCR instrument.

Western blot analysis used to detect the expression of protein. Total protein of breast cancer and adjacent tissues were extracted according to the instructions of cell total protein extraction kit. The concentration of extracted protein was determined by bicinchoninic acid protein assay and protein samples were stored at $-70^{\circ} \mathrm{C}$. Protein samples were subjected to electrophoresis with different concentrations of SDS-PAGE
Table I. Primers used for PCR reaction.

\begin{tabular}{ll}
\hline Proteins & \multicolumn{1}{c}{ Primers } \\
\hline CD24 & F: 5'-TTCTCCAAGCACCCAGCA-3' \\
& R: 5'-TGGAATAAATCTGCGTGGGTA-3' \\
B7-H3 & F: 5'-ACCATCACAGGGCAGCCTAT-3' \\
& R: 5'-TCCTCAGCTCCTGCATTCTC-3' \\
GAPDH & F: 5'-TGGGTGTGAACCACGAGAA-3' \\
& R: 5'-GGCATGGACTGTGGTCATGA-3'
\end{tabular}

F, forward; R, reverse.

gel. According to the protein marker, the positions of the two proteins were determined. After transmembrane to polyvinylidene difluoride membrane, the membranes were blocked with $5 \%$ skimmed milk at $37^{\circ} \mathrm{C}$ for $90 \mathrm{~min}$. The membranes were then blocked with mouse anti-human CD24 (1:1,000; cat. no. 560991) and B7-H3 (1:1,000; cat. no. 565829) monclonal antibody overnight at $4^{\circ} \mathrm{C}$. After washing with Tris-buffered saline and Tween-20 (TBST) solution 3 times, 15 min each time, the membranes were incubated with the goat anti-mouse polyclonal secondary antibody $(1: 1,000$; cat. no. 554002$)$ at $37^{\circ} \mathrm{C}$ for $1 \mathrm{~h}$. After washing with TBST solution 3 times, 15 min per time, the membranes were incubated with electrochemiluminescence (ECL) liquid in the dark for color development. The results were scanned by ChemiDocTMMP imaging system. Image J professional analysis software was used to analyze the results with GAPDH as an endogenous control.

Survival analysis. All 74 patients with breast cancer were followed up for 5 years and the survival status of the patients was recorded.

Statistical analysis. SPSS17.0 (SPSS, Inc., Chicago, IL, USA) was used for data analysis. Measurement data were expressed as mean \pm standard deviation and comparisons between groups were performed by t-test. The comparisons of positive expression rate between groups were performed by the $\chi^{2}$ test. The correlation between two proteins was analyzed by Spearman's rho test. GraphPad Software, Inc. (La Jolla, CA, USA) Prism 5 was used for survival analysis. $\mathrm{P}<0.05$ was considered to indicate a statistically significant analysis.

\section{Results}

Expression of CD24 in breast cancer and adjacent tissues. Results of the present study showed that CD24 was expressed strongly in breast cancer tissues but weakly in adjacent tissues. CD24 was mainly expressed in cell membrane and cytoplasm staining was relatively weak (Fig. 1).

In 74 cases of breast cancer tissue, CD24-positive expression was observed in 56 cases and the positive rate was $75.7 \%$. In 74 cases of adjacent tissues, CD24-positive expression was observed in 19 cases and the positive rate was $25.7 \%$. The positive expression rate of CD24 in breast cancer tissues was significantly higher than that in adjacent tissues $(\mathrm{P}<0.01)$, (Table II). 
Table II. Expression of CD24 in breast cancer and adjacent tissues.

\begin{tabular}{lccccc}
\hline & & \multicolumn{2}{c}{ CD24 } & & \\
\cline { 3 - 5 } Groups & Cases & + & - & Positive & \\
& & & & & \\
Cancer tissue & $\%$ & P-value \\
Adjacent tissue & 74 & 56 & 18 & 75.7 & $<0.01$ \\
\hline
\end{tabular}
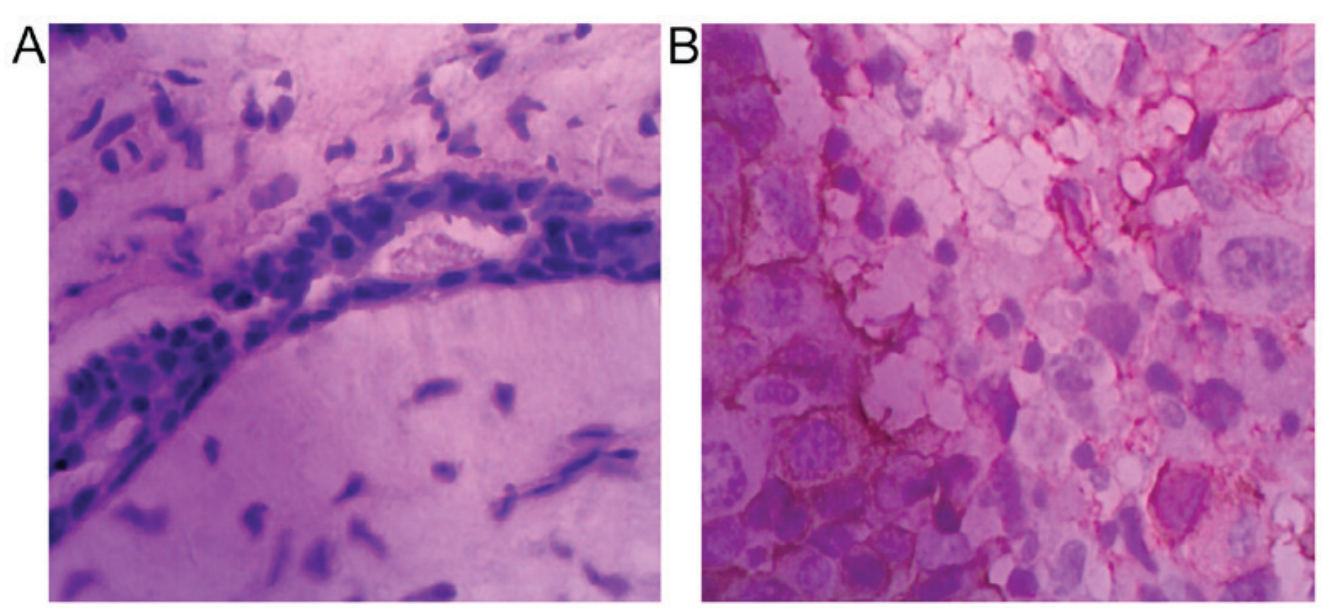

Figure 1. CD24 immunohistochemical results in (A) adjacent and (B) breast cancer tissues. Magnification, x400. CD24 is weakly expressed in adjacent and strongly in breast cancer tissues.
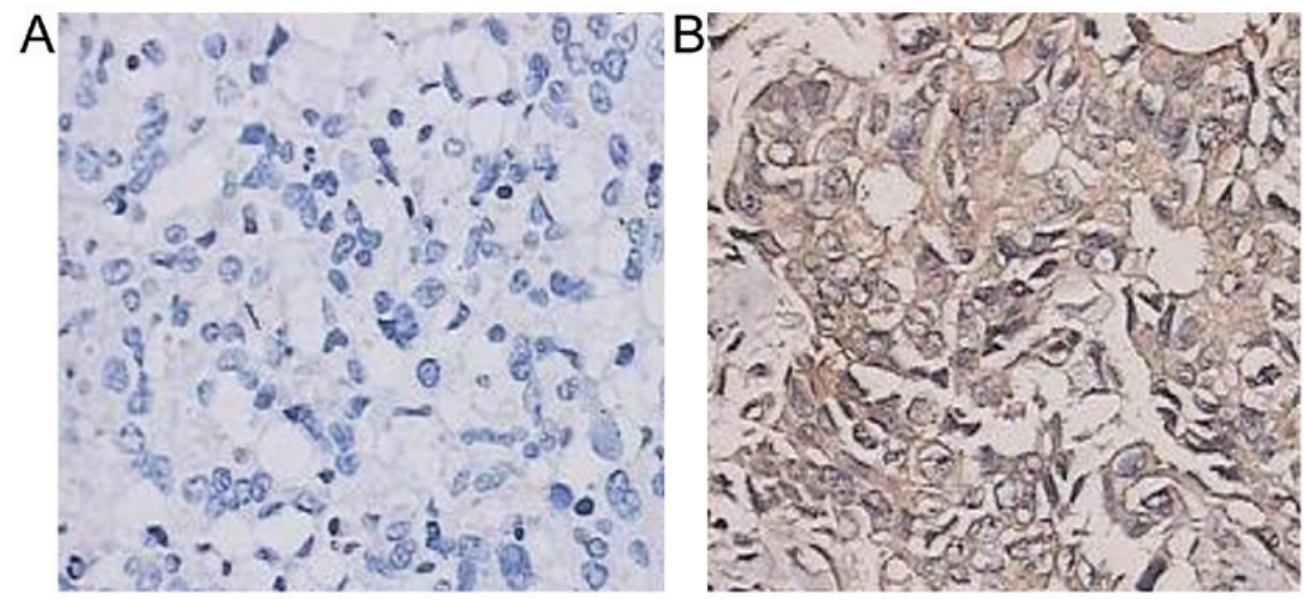

Figure 2. B7-H3 immunohistochemical results in (A) adjacent and (B) breast cancer tissues. Magnification, $\mathrm{x} 400$. B7-H3 is weakly expressed in adjacent tissues but strongly in breast cancer tissues and B7-H3 expression was mainly observed in cell membrane and cytoplasm.

B7-H3 expression in breast cancer and adjacent tissues. Results of immunohistochemistry showed that B7-H3 was expressed weakly in adjacent tissues but strongly in breast cancer tissues and B7-H3 expression was mainly observed in the cell membrane and cytoplasm (Fig. 2).

A positive rate of B7-H3 was $56.8 \%$ (42/74) in 74 cases of breast cancer tissue. The positive rate of B7-H3 was $43.2 \%$ (32/74) in 74 cases of adjacent tissues (Table III). B7-H3 expression in breast cancer and adjacent tissues were compared and the expression rate of B7-H3 in breast cancer tissues was significantly higher than that of adjacent tissues $(\mathrm{P}<0.05)$.

Table III. Expression of B7-H3 in breast cancer and adjacent tissues.

\begin{tabular}{lccccc}
\hline & \multicolumn{4}{c}{ B7-H3 } & \\
\cline { 3 - 5 } Groups & Cases & + & - & $\begin{array}{l}\text { Positive } \\
\text { rate (\%) }\end{array}$ & P-value \\
\hline Cancer tissue & 74 & 42 & 32 & 56.8 & $<0.05$ \\
Adjacent tissue & 74 & 32 & 42 & 43.2 & \\
\hline
\end{tabular}


Table IV. Correlation between the expression of CD24 and B7-H3 in breast cancer tissue.

\begin{tabular}{lrrrrrr}
\hline & & \multicolumn{2}{c}{ B7-H3 } & & & \\
\cline { 2 - 3 } Groups & \multicolumn{1}{c}{+} & - & Total & r & P-value \\
\hline CD24 & 25 & 56 & 0.297 & 0.036 & & \\
& - & 11 & 7 & 18 & & \\
Total & & 42 & 32 & 74 & & \\
\hline
\end{tabular}

r, Spearman's rho.

Table V. Expression of CD24 and B7-H3 mRNA in cancer and adjacent tissues determined by quantitative PCR.

\begin{tabular}{lcc}
\hline Groups & CD24 & B7-H3 \\
\hline Cancer tissue & $42.7 \pm 2.19$ & $58.2 \pm 3.35$ \\
Adjacent tissue & $28.3 \pm 4.37^{\mathrm{a}}$ & $31.7 \pm 5.26^{\mathrm{b}}$ \\
t-test & 4.014 & 5.136 \\
P-value & $<0.05$ & $<0.05$ \\
\hline
\end{tabular}

${ }^{\mathrm{a}}$ Compared with $\mathrm{CD} 24$ in cancer tissue, $\mathrm{p}<0.05$. ${ }^{\mathrm{b}}$ Compared with B7-H3 in cancer tissue, $\mathrm{p}<0.05$.

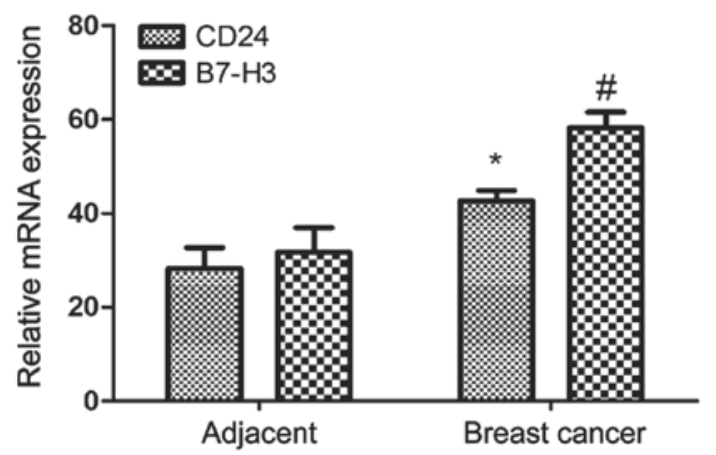

Figure 3. Relative expression levels of $\mathrm{CD} 24$ and $\mathrm{B} 7-\mathrm{H} 3$ mRNA in breast cancer and adjacent tissues. ${ }^{\#} \mathrm{P}<0.05 ;{ }^{*} \mathrm{P}<0.05$.

single peaks, indicating the high specificity of primers. The relative expression levels of CD24 mRNA in breast cancer and adjacent tissues were $42.7 \pm 2.19$ and $28.3 \pm 4.37$, respectively. A significant difference was found between them $(\mathrm{P}<0.05)$. The relative expression levels of B7-H3 mRNA were 58.2 \pm 3.35 and 31.7 \pm 5.26 , respectively. A significant difference was also found between them $(\mathrm{P}<0.05)$ (Table V and Fig. 3).

Western blot analysis. The expression rate of CD24 in adjacent tissues was significantly lower than that in breast cancer $(\mathrm{P}<0.05)$, while the expression rate of $\mathrm{B} 7-\mathrm{H} 3$ in breast cancer tissues was significantly higher than that in adjacent tissues $(\mathrm{P}<0.05)$ (Table VI and Fig. 4).

Relationship between the expression of CD24 and B7-H3 and the prognosis of breast cancer patients. The survival of
Table VI. Expression of CD24 and B7-H3 detected by western blot analysis.

\begin{tabular}{lcc}
\hline Groups & CD24 & B7-H3 \\
\hline Cancer tissue & $0.741 \pm 0.075$ & $0.865 \pm 0.046$ \\
Adjacent tissue & $0.592 \pm 0.062^{\mathrm{a}}$ & $0.669 \pm 0.037^{\mathrm{b}}$ \\
t-test & 3.911 & 4.624 \\
P-value & $<0.05$ & $<0.05$ \\
\hline
\end{tabular}

${ }^{\mathrm{a} C}$ Compared with CD24 in cancer tissue, $\mathrm{p}<0.05$. ${ }^{\mathrm{b}}$ Compared with B7-H3 in cancer tissue, $\mathrm{p}<0.05$.

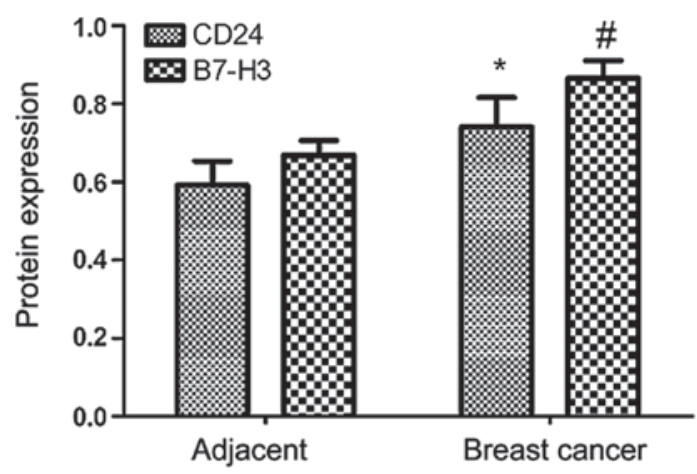

Figure 4. Expression of CD24 and B7-H3 detected by western blot analysis. ${ }^{\text {\#P }}<0.05 ;{ }^{*} \mathrm{P}<0.05$

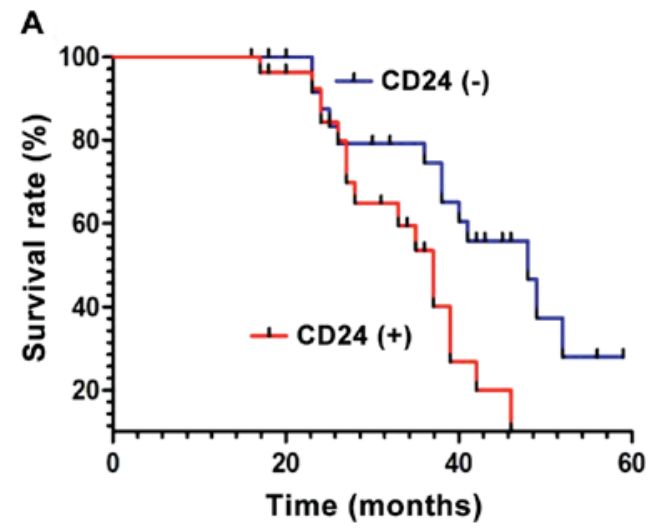

B

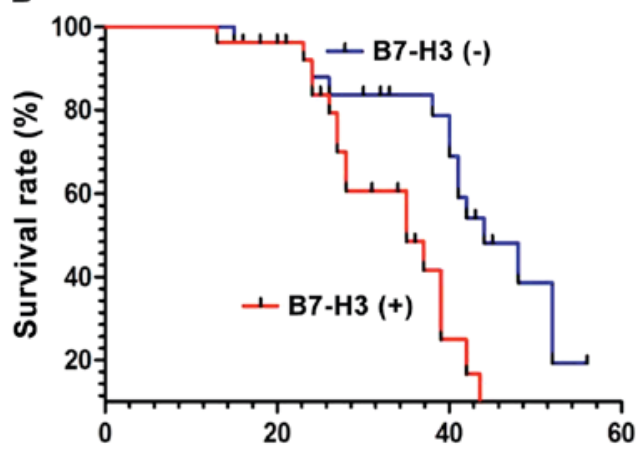

Figure 5. Survival curves of patients with a positive and negative expression of CD24 and B7-H3 protein. The survival rate of patients with negative CD24 protein expression was higher than that of patients with positive CD24 protein expression $\left(\chi^{2}=8.673, \mathrm{P}<0.05\right.$, Fig. $\left.5 \mathrm{~A}\right)$. In addition, the survival rate of patients with negative $\mathrm{B} 7-\mathrm{H} 3$ protein expression was also higher than that of patients with positive B7-H3 protein expression $\left(\chi^{2}=7.496, \mathrm{P}<0.05\right.$, Fig. $\left.5 \mathrm{~B}\right)$. 
patients with a positive and negative expression of CD24 and B7-H3 protein was compared. The survival rate of patients with a negative CD24 protein expression was higher than that of patients with a positive CD24 protein expression $\left(\chi^{2}=8.673\right.$, $\mathrm{P}<0.05$, Fig. 5A). In addition, the survival rate of patients with a negative $\mathrm{B} 7-\mathrm{H} 3$ protein expression was also higher than that of patients with a positive B7-H3 protein expression $\left(\chi^{2}=7.496\right.$, $\mathrm{P}<0.05$, Fig. 5B).

\section{Discussion}

In previous years, the incidence of breast cancer as a type of female malignant tumor has been on the increase and numerous studies on the development and metastasis of breast cancer have been carried out. CD24 is an adherent molecule with a relative low molecular weight. CD24 can adhere to cell membranes through glycosyl-phosphatidyl inositol and the abnormal expression of CD24 has been detected in a variety of malignant tumors (8-10). Therefore, it is generally believed that CD24 is associated with metastases of malignant tumors $(11,12)$. A new co-stimulus factor was first reported in 2001 and later confirmed to be B7-H3, which is one of the B7 families (13-15). Previous findings have shown that B7-H3 usually plays a role as a negative regulator in many malignant tumors (16). Liu et al (17) found that B7-H3 was expressed in a variety of non-small cell lung cancer cell lines and B7-H3 expression was located on cytoplasm and membrane. Additionally, B7-H3 was overexpressed in prostate cancer tissues and the expression level of B7-H3 was positively correlated with clinical staging (18). Kim et al (19) found that colorectal cancer patients usually showed a high expression level of B7-H3 and those patients were usually accompanied by tumor-infiltrating and increased lymphocytes $(20,21)$, indicating that the positive expression of B7-H3 was positively correlated with tumor metastasis.

The expression of CD24 and B7-H3 was detected and statistically analyzed. The results showed that CD24 and B7-H3 were abnormally expressed in breast cancer and adjacent tissues and the positive rates were 75.7 and $25.7 \%$, respectively, while the positive rates of B7-H3 were 56.8 and $43.2 \%$, respectively, and the differences were statistically significant $(\mathrm{P}<0.05)$. This finding was consistent with that of previous studies. CD24 expression was positively related to the expression of B7-H3 (Spearman's correlation coefficient $\mathrm{r}, 0.297$; $\mathrm{p}, 0.036$ ), indicating the involvement of CD24 and B7-H3 in the occurrence and metastasis of breast cancer. Significant differences in the 5-year survival were found between patients with a positive and negative expression of CD24 and B7-H3 (P<0.05). Results of RT-qPCR showed that expression levels of CD24 and B7-H3 mRNA in breast cancer tissues were significantly higher than those in adjacent tissues $(\mathrm{P}<0.05)$. Results of western blot analysis revealed that the expression levels of CD24 and B7-H3 protein in breast cancer tissues were also significantly higher than those in adjacent tissues $(\mathrm{P}<0.05)$. The results suggest that the positive expression of CD24 was positively correlated with the positive expression of B7-H3. Our study therefore provides guidance for the diagnosis of breast cancer.

In summary, we investigated the expression of CD24 and B7-H3 in breast cancer and adjacent tissues, and discussed the possible roles of CD24 and B7-H3 in the diagnosis and prognosis of breast cancer. Further studies are required to confirm the findings of this study.

\section{References}

1. Onishi H, Suyama K, Yamasaki A, Oyama Y, Fujimura A, Kawamoto $M$ and Imaizumi A: CD24 modulates chemosensitivity of MCF-7 breast cancer cells. Anticancer Res 37: 561-565, 2017.

2. Tramm T, Kim JY, Leibl S, Moinfar F and Tavassoli FA: Expression of C-KIT, CD24, CD44s, and COX2 in benign and non-invasive apocrine lesions of the breast. Virchows Arch 469: 285-295, 2016.

3. Cremers N, Neeb A, Uhle T, Dimmler A, Rothley M, Allgayer H, Fodde R, Sleeman JP and Thiele W: CD24 is not required for tumor initiation and growth in murine breast and prostate cancer models. PLoS One 11: e0151468, 2016.

4. Suyama K, Onishi H, Imaizumi A, Shinkai K, Umebayashi M, Kubo M, Mizuuchi Y, Oda Y, Tanaka M, Nakamura M, et al: CD24 suppresses malignant phenotype by downregulation of SHH transcription through STAT1 inhibition in breast cancer cells. Cancer Lett 374: 44-53, 2016.

5. Chen Y, Song J, Jiang Y, Yu C and Ma Z: Predictive value of CD44 and CD24 for prognosis and chemotherapy response in invasive breast ductal carcinoma. Int J Clin Exp Pathol 8: $11287-11295,2015$

6. Kwon MJ, Han J, Seo JH, Song K, Jeong HM, Choi JS, Kim YJ, Lee SH, Choi YL and Shin YK: CD24 overexpression is associated with poor prognosis in luminal $\mathrm{A}$ and triple-negative breast cancer. PLoS One 10: e0139112, 2015.

7. Kapucuoğlu N, Bozkurt KK, Başpınar Ş, Koçer M, Eroğlu HE, Akdeniz R and Akçil M: The clinicopathological and prognostic significance of CD24, CD44, CD133, ALDH1 expressions in invasive ductal carcinoma of the breast: CD44/ CD24 expression in breast cancer. Pathol Res Pract 211: 740-747, 2015.

8. Wu CP, Jiang JT, Tan M, Zhu YB, Ji M, Xu KF, Zhao JM, Zhang GB and Zhang XG: Relationship between co-stimulatory molecule B7-H3 expression and gastric carcinoma histology and prognosis. World J Gastroenterol 12: 457-459, 2006.

9. Sun Y, Wang Y, Zhao J, Gu M, Giscombe R, Lefvert AK and Wang X: B7-H3 and B7-H4 expression in non-small-cell lung cancer. Lung Cancer 53: 143-151, 2006.

10. Crispen PL, Sheinin Y, Roth TJ, Lohse CM, Kuntz SM, Frigola X, Thompson RH, Boorjian SA, Dong H, Leibovich BC, et al: Tumor cell and tumor vasculature expression of $\mathrm{B} 7-\mathrm{H} 3$ predict survival in clear cell renal cell carcinoma. Clin Cancer Res 14: 5150-5157, 2008.

11. Roth TJ, Sheinin Y, Lohse CM, Kuntz SM, Frigola X, Inman BA, Krambeck AE, McKenney ME, Karnes RJ, Blute ML, et al: B7-H3 ligand expression by prostate cancer: A novel marker of prognosis and potential target for therapy. Cancer Res 67: 7893-7900, 2007.

12. Zang X, Thompson RH, Al-Ahmadie HA, Serio AM, Reuter VE, Eastham JA, Scardino PT, Sharma P and Allison JP: B7-H3 and $\mathrm{B} 7 \mathrm{x}$ are highly expressed in human prostate cancer and associated with disease spread and poor outcome. Proc Natl Acad Sci USA 104: 19458-19463, 2007.

13. Buck K, Hug S, Seibold P, Ferschke I, Altevogt P, Sohn C, Schneeweiss A, Burwinkel B, Jäger D, Flesch-Janys D, et al: CD24 polymorphisms in breast cancer: Impact on prognosis and risk. Breast Cancer Res Treat 137: 927-937, 2013.

14. Huang LW and Lee CC: Cluster of differentiation 24 expression is an independent prognostic factor of adverse outcome in cervical carcinoma. Int J Gynecol Cancer 23: 325-330, 2013.

15. Chapoval AI, Ni J, Lau JS, Wilcox RA, Flies DB, Liu D, Dong H, Sica GL, Zhu G, Tamada K, et al: B7-H3: A costimulatorymolecule for $\mathrm{T}$ cell activation and IFN-gamma production. NatImmunol 2: 269-274, 2001.

16. King JB, von Furstenberg RJ, Smith BJ, McNaughton KK, Galanko JA and Henning SJ: CD24 can be used to isolate Lgr5+ putative colonic epithelial stem cells in mice. Am J Physiol Gastrointest Liver Physiol 303: G443-G452, 2012.

17. Liu B, Yang Y, Han S, Zhang L, Bai Y and Fang X: Plasma CD24 as a novel useful biomarker in differentiating hepatocellular carcinoma patients from normal individuals. Hepatogastroenterology 60: 1245-1250, 2013. 
18. Sun X, Vale M, Leung E, Kanwar JR, Gupta R and Krissansen GW: Mouse B7-H3 induces antitumor immunity. Gene Ther 10: 1728-1734, 2003.

19. Kim J, Myers AC, Chen L, Pardoll DM, Truong-Tran QA, Lane AP, McDyer JF, Fortuno L and Schleimer RP: Constitutive and inducible expression of b7 family of ligands by human airway epithelial cells. Am J Respir Cell Mol Biol 33: 280-289, 2005.

20. Fukushima A, Sumi T, Fukuda K, Kumagai N, Nishida T, Yamazaki T, Akiba H, Okumura K, Yagita H and Ueno H: B7-H3 regulates the development of experimental allergic conjunctivitis in mice. Immunol Lett 113: 52-57, 2007.
21. Ricardo S, Vieira AF, Gerhard R, Leitão D, Pinto R, Cameselle-Teijeiro JF, Milanezi F, Schmitt F and Paredes J: Breast cancer stem cell markers CD44, CD24 and ALDH1: Expression distribution within intrinsic molecular subtype. J Clin Pathol 64: 937-946, 2011. 